\title{
ALEGORIA W HISTORII POWSZECHNEJ TEOFILAKTA SIMOKATTY. PRZYCZYNEK DO BADAŃ NAD OBECNOŚCIĄ ALEGORII W LITERATURZE BIZANTYŃSKIEJ
}

Słowa kluczowe: Teofilakt Simokatta, Focjusz, historiografia bizantyńska, alegoria, Słowianie Keywords: Theophylact Simocatta, Photius, Byzantine historiography, allegory, Slavs

\section{Wprowadzenie}

Teofiakt Simokatta urodził się w latach 70-tych VI wieku w Egipcie, zmarł natomiast w latach trzydziestych następnego stulecia. Swoją karierę urzędniczą rozpoczął w Aleksandrii. Konstantyn Porfirogeneta podaje informację, że osiągnął on najwyższy możliwy urząd w Egipcie - eparchy ${ }^{1}$, lecz brak potwierdzenia przez inne źródła czyni tę informację niepewną. W 610 roku wyrusza wraz z przyszłym cesarzem Herakliuszem do Konstantynopola. W stolicy, związany z nowym kierownictwem państwa, pracował w administracji centralnej imperium, choć bliższym szczegółów nie znamy. Pozostawił po sobie Historię powszechna - opis wydarzeń ostatniego dwudziestolecia VI wieku, okresu panowania cesarza Maurycjusza (582-602), jakkolwiek poprzez odniesienia sięga w przeszłość po końcowe lata panowania Justyniana I. Historia uważana jest za ostatnie dzieło historiografii starożytnej, bardzo rzetelne w przedstawianiu wydarzeń: m.in. najazdu Słowian na Bałkany, przybycia Awarów do Europy, wojny Cesarstwa z Persją i wewnętrznego konfliktu w państwie Sasanidów. Nadal zagadką dla historyków pozostaje też opis azjatyckiego kraju Tabgacz w księdze siódmej².

\footnotetext{
${ }^{1}$ Excerpta de legationibus, ed. De Boor, Berolini 1903, 221; 447.

${ }^{2}$ Wszystkie thumaczenia z Historii powszechnej na podstawie: Anna Kotłowska, Łukasz Różycki, Teofilakt Simokatta. Historia powszechna („Rhomaioi” 7, Poznań: Wydawnictwo Naukowe UAM, 2016).
} 
Tak ważna dla poznania niespokojnej epoki przełomu synteza nadal nie doczekała się szczegółowych studiów historycznych, a tym bardziej filologicznych. W niniejszym artykule próbuję, poprzez analizę jednego aspektu, wypełnić tę lukę.

\section{Focjusz i alegoria w dziele Teofilakta}

Patriarcha Focjusz (ok. 810 - ok. 893), pisząc streszczenie Historii powszechnej Teofilakta Simokatty, następującymi słowami ocenił styl jego narracji (cod. 65, ed. R. Henry, Parisiis MCMLIX quem correxit P. Wirth, Theophylacti Simocattae, Stutgardiae MCMLXXII, p. XXVIII et 3):

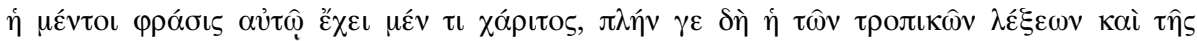

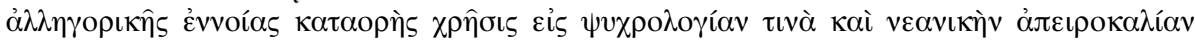

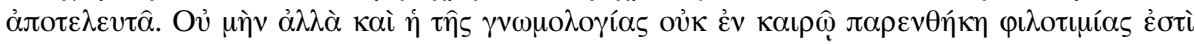

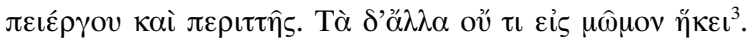

Jego styl ma w sobie trochę wdzięku, jednak nadużywanie słów metaforycznych i alegorii prowadzi do pewnego rodzaju oziębłości i młodzieńczego braku smaku. Co więcej, dodatkowe wprowadzanie sentencji, i to nie we właściwym miejscu jest oznaką zbytniej i osobliwej troski. Co do reszty, nie ma go w czym ganić4

Kluczowym punktem tej zaskakująco ostrej recenzji jest zarzut „braku sma-

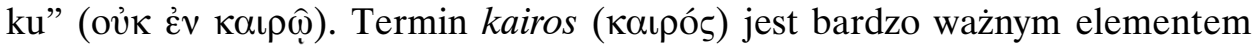
greckiej kultury, wpływającym na definiowanie normatywne, estetyczne, czy nawet etyczne. Mianowicie to uznanie, czy coś mieści się w ramach kairos, determinuje jego wartościowanie. Tak fundamentalne dla każdej kultury słowa są zwykle trudne do przekładu na inny język. Należy zatem zacząć od stwierdzenia, że kairos to właściwy czas i miejsce każdej rzeczy. Wszystkie nasze czynności, obyczaje i obowiązki powinny odbywać się w stosownej ku temu chwili i w miejscu dla nich przeznaczonym. Wówczas udaje się zachować ład (kosmos,

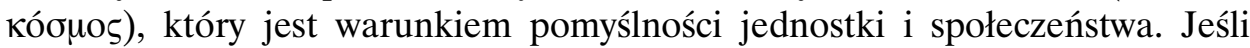
natomiast postępujemy $-\mathrm{z}$ rozmaitych przyczyn - wbrew tym zasadom ( $\tau \alpha \dot{\xi} \xi \varepsilon \iota)$ ),

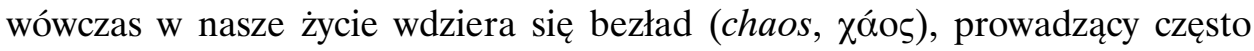

${ }^{3}$ O Bibliotece: Thomas Hägg, Photios als Vermittler antiker Literatur: Untersuchungen zur Technik des Referierens und Exczerpierens in der Bibliotheke (Stockholm: Almqvist och Wiksell, 1975); Warren Treadgold, The Nature of the Bibliotheca of Photius (Washington DC: Dumbarton Oaks Publications 1980); Józef Naumowicz, Wczesnochrześcijańscy pisarze aleksandryjscy w Bibliotece Focjusza („Archiwum Filologiczne” 53, Wrocław: Zakład Narodowy im. Ossolińskich, 1995).

${ }^{4}$ Przekład Oktawiusz Jurewicz, Focjusz. Biblioteka. Tom I: Kodeksy 1-150 (Wrocław: Zakład Narodowy im. Ossolińskich, 2006), 63. 
do konfliktów i kryzysu tak w życiu prywatnym, jak i społeczno-państwowym ${ }^{5}$. Nietrudno zatem zrozumieć teraz znaczenie kairos w sztuce, w tym i w literaturze. Zachowanie norm estetycznych gwarantuje piękno dzieła sztuki (rzeźby, utworu literackiego ${ }^{6}$ itp.) oraz jego właściwe oddziaływanie na odbiorcę, ich przekroczenie natomiast, pozbawia dzieło wartości, a przynajmniej znacznie je deprecjonuje. Spostrzeżenia powyższe rzutują oczywiście na kwestię polskiego oddania tego terminu. Jest rzeczą bezdyskusyjną, iż w naszym języku nie istnieje prosty jego odpowiednik i słowo kairos zawsze będzie tłumaczone z uwzględnieniem kontekstu. W przypadku zacytowanego fragmentu Focjusza, zasłużony bizantynista i tłumacz Oktawiusz Jurewicz (1926-2016) ${ }^{7}$ zdecydował się na słowo „smak”. Jest to thumaczenie niewątpliwie poprawne i słuszne, ale - jak zobaczymy niżej - nie oddaje ono ostrości zarzutu. „Smak” lub „brak smaku” w języku polskim brzmi zbyt delikatnie i nie jest adekwatne w kontekście wypowiedzi Focjusza. Główne zagrożenie kryje się wszakże w tym, że, przyznajmy, „smak” nosi w sobie ziarna subiektywizmu. Każdy może mieć inny „smak”, troszkę odmienne „poczucie estetyki”. Tymczasem kairos jest kwintesencją obiektywizmu, istnieje niezależnie, gdyż od jego norm zależy istnienie kosmosu. Nie możemy o tym zapominać, gdyż inaczej nie zrozumiemy istoty kultury klasycznej. Dlatego potrzebny jest dodatkowy komentarz.

W retoryce klasycznej alegoria przynależy do tropów myślowych (tropus sermonis), jest metaforą wykraczającą poza związek dwóch słów (allegoriam facit continua metaphora), bądź nawet zdanie. Znaczenie domyślne, ukryte pod dosłownym, obejmuje sobą szerszą ideę lub ich zespół i często jest powiązane $\mathrm{z}$ tradycją literacką. W literaturze bizantyńskiej to uzależnienie od przeszłości jest szczególnie silne, gdyż cała jej estetyka opiera się na idei mimesis, a więc na przekonaniu, iż im bardziej twórczość nasza bliska jest wzorcom klasycznym, tym jest wartościowsza ${ }^{8}$. Dlatego też nie należy czynić bizantyńskim pisarzom zarzutu, iż powtarzają dawne obrazy, symbole i przysłowia, lecz pytać, czy czynią to adekwatnie. Owa ,adekwatność” właśnie została przez Focjusza zakwestionowana. Uznał on bowiem, że użyte przez Teofilakta środki stylistyczne,

${ }^{5}$ Ekstremalnym przykładem takiego myślenia jest polityczna refleksja Platona, który - na podstawie osobistych złych doświadczeń z demokracją - zaproponował w Państwie i w Prawach model ustroju totalitarnego - kairos w formie idealnej. Bardzo dobrze pisał o tym Karl Raimund Popper w dziele Społeczeństwo otwarte i jego wrogowie (Warszawa: Wydawnictwo Naukowe PWN, 2006).

${ }^{6}$ Vide przykładowe studium: Bernard Gallet, Recherches sur Kairos et l'ambiguite dans la poesie de Pindare (Bordeaux: Presses Universitaires de Bordeaux, 1990).

${ }^{7}$ Andrzej Kompa, Mirosław J. Leszka, „Professor Oktawiusz Jurewicz as a Byzantinist (1926-2016)", Studia Ceranea, no. 6 (2016): 11-22; artykuł zawiera pełną bibliografię twórczości uczonego. Vide krótkie notki biograficzne Michała Kozłowskiego: Nowy Filomata, no. 20:1 (2016): 3-5, Meander, no. 71 (2016): 3-7, Symbolae Philologorum Posnaniensium, no. 26:2 (2016): 153-157.

${ }^{8}$ Herbert Hunger, „On the Imitation (MIMESIS) of Antiquity in Byzantine Literature”, Dumbarton Oaks Papers, no. 23-24 (1969-1970): 15-38. 
w tym i alegoria, zostały użyte w niewłaściwy sposób, nieadekwatnie do opisywanej sytuacji, czyli właśnie „bez smaku”.

Zauważmy przy tym, iż ten jeden zarzut zdominował całokształt oceny Historii powszechnej. Jej duża wartość jako źródła historyczego dla poznania pierwszego stulecia obecności Słowian na Bałkanach, czy historii Persji Sasanidów ostatniej ćwierci VI wieku została skwitowana ogólnym „co do reszty nie

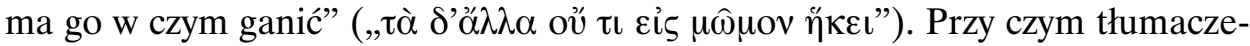
nie polskie nie w pełni oddaje tutaj siłę przekazu oryginału. Otóż dosłownie należałoby oddać powyższą fraze przez „,reszta nie prowadzi do hańby”. Kluczowy jest tu rzeczownik momos ( $\mu \hat{\omega} \mu \mathrm{o})$, bardzo silnie nacechowany emocjonalnie i radykalnie pejoratywny: „hańba, nagana, zepsucie, potępienie itp.” Zatem, skoro pozostała zawartość dzieła Teofilakta nie jest przedmiotem momosu, to wynika $z$ tego, iż to, co było na początku krytykowane, a więc i niewłaściwe użycie alegorii, jak najbardziej tak. To bardzo mocna i jednoznacznie negatywna konkluzja. Należy przy tym pamiętać, iż Kallimach z Cyreny (ok. 310 - ok. 235 r. p.n.e.) w ostatnim wersie Hymnu do Apollona wzywa boga, by ten zabrał odeń momos razem z zawiścią. Focjusz z pewnością o tym wiedział i gdy sam pisał o momosie, myślał o nim tak, jak wielki poeta aleksandyjski - nie ma większego zagrożenia dla pisarza niż być obiektem momosu.

W poniższym artykule przeanalizowane zostaną wszystkie obrazy alegoryczne, zamieszczone przez Teofilakta. Poza obszarem badawczym znajdą się pozostałe struktury narracyjne, jakkolwiek ich pobieżna lektura wskazuje na słuszność słów patriarchy. Otóż w prozie Teofilakta spotkać można przykłady zastosowania różnorodnych środków stylistycznych, mniej (np. bombastyczna mowa biskupa Domicjana $^{9}$, nietrafiona metafora „miecza złej sprawiedliwości”"10, niebywale pretensjonalna „cykliczna hebdomada" 11 zamiast „tygodnia” itp.) lub bardziej udanych (np. ekfraza przyrody ${ }^{12}$; przysłowie $\mathrm{z}$ wilkiem ${ }^{13}$ ). Do tych ostatnich zaliczyć należy stosunkowo liczne, acz wierne, cytaty z eposów Homera ${ }^{14}$, którego Teofilakt określa tradycyjnie i z szacunkiem mianem Poety. Tak np. o perskiej świętej imieniem Golinduch pisze: „Wszakże «kim była i skąd» ta kobieta, mówiąc słowami Poety, zaraz przedstawimy"15.

${ }^{9}$ Theoph. Sim., 4.16.

${ }^{10}$ Theoph. Sim., 4.6. W tego typu egzaltowanych wyrażeniach Teofilakt jest rozmiłowany, znajdziemy ich bardzo wiele, zwłaszcza w przemowach, ale ich cytowanie, ze względu na kompletny brak wyczucia ze strony autora, wydaje się zbędne.

${ }^{11}$ Theoph. Sim., 2.2.

${ }^{12}$ Theoph. Sim., 2.11.

${ }^{13}$ Theoph. Sim., 2.17.

${ }^{14}$ Podstawową edycją pozostaje Thomas William Allen, Homeri Opera, t. 1-5 (Oxonii: Oxford University Press 1912). Tekst polski Iliady za wielokrotnie wznawianym, znakomitym przekładem Kazimiery Jeżewskiej.

${ }^{15}$ Theoph. Sim., 5.12 (trans. Anna Kotłowska, Łukasz Różycki; dalej: AK, ŁR). 
„Kim była i skąd” to cytat z Odysei (15.423), gdzie słowa te odnoszą się do fenickiej branki. To dość zaskakujące połączenie, które pokazuje, że w tym miejscu Teofilaktowi nie zależało na głębszych relacjach i grze kontekstów, lecz jedynie na wykorzystanie czystego cytatu, by ubarwić epizod Golinduch i udowodnić przed odbiorcą znajomość eposu. Wszakże ewidentna sztuczność tego zabiegu zdaje się potwierdzać opinię Focjusza. Zupełnie inaczej wygląda wykorzystanie cytatu w kontekście oceny katastrofalnej sytuacji w prowincjach wschodnich w 588-589 roku Teofilakt pisze:

Bunt ten miał fatalne konsekwencje dla Wschodu, „bo zewsząd nań ciosy po ciosach spadały”, by przypomnieć słowa Poety: jedni stracili cały majątek, inni zostali ograbieni podczas podróży, na polach, a tyrania rozkwitała i dawała przyzwolenie dla krzywd ${ }^{16}$.

Rozmiar kryzysu: zagrożenie zewnętrzne i bunt armii zostały zilustrowane cytatem z Iliady (16.111), gdzie oznacza on wycofywanie się Ajasa, syna Telamona, pod naciskiem Trojan. W tym przypadku cytat wzmacnia ocenę etyczną opisywanego wydarzenia. Prawowity rząd w Konstantynopolu i ludność prowincji wschodnich cierpi pod naporem zła zewnętrznego i wewnętrznego (bunt armii, „tyrania” - opozycja wobec Maurycjusza). Zamieszczając tak sprytnie dobrany cytat Teofilakt broni swojej argumentacji, swojej oceny bieżących wydarzeń politycznych. Podobnie adekwatnie wybrzmiał fragment eposu w ustach rzymskiego oficera, który przeczuwa śmierć cesarza Maurycjusza: „Zatruty takim uczuciem imperator «może niebawem stracić życie», że ozdobię wypowiedź słowem tragedii Homerowej" ${ }^{17}$. Słowa te wypowiedział Achilles, grożąc Agamemnonowi Atrydzie (Iliada,1.875). Brzmią one w tym miejscu przejmująco: Maurycjusz staje się drugim Agamemnonem, wybitnym władcą, który odniósł wielkie zwycięstwo tylko po to, by zostać podstępnie zamordowanym przez miernoty.

Mało wyrafinowane, ale dość zręcznie wplecione w narrację, są fragmenty eposu wzbogacające sceny batalistyczne. Ich obecność pozwala na wyrażenie uznania dla współczesnych sobie żołnierzy, których męstwo dorównywać ma temu z czasów herosów ${ }^{18}$. Czyż może istnieć większa pochwała, niż porównanie do Achillesa? I większe pocieszenie, gdy nasza klęska przypomina klęskę Troi? Pieśni Poety mogą wreszcie służyć jako ilustracja życiowej prawdy, potwierdzając komentarz autora, który w ten sposób ratuje się przed truizmem: dlatego banalne skądinąd twierdzenie o zmienności losu, zostało zilustrowane cytatem, iż „Zwycięstwo różnych spotyka mężów” (Iliada, 6.339) ${ }^{19}$.

\footnotetext{
${ }^{16}$ Theoph. Sim., 3.2 (trans. AK, ŁR).

${ }^{17}$ Theoph. Sim., 8.7.

${ }^{18}$ Theoph. Sim., 2.18 i Iliada, 5.586; Theoph. Sim., 4.15 i Iliada, 4.43; Theoph. Sim., 7.4 i Iliada,

${ }^{19}$ Theoph. Sim., 2.17.
} 11.547. 
Reasumując, wykorzystanie przez Teofilakta cytatów z eposu należy ocenić pozytywnie. Są one na ogół (poza jednym przypadkiem) uzasadnione, dobrze, bez nachalności, wkomponowane w tekst, niewątpliwie spełniając swoją funkcję: zwiększają satysfakcję z lektury, wzmacniając autorytet głównego przekazu.

Ścisłej kategoryzacji nie poddaje się interesująca opowieść o pojawieniu się w Nilu magicznych istot. Obecność rozmaitych miracula, które szybko stawały się memorabilia, była zawsze szeroko komentowana w literaturze klasycznej i Teofilakt absolutnie nie stanowi tu żadnego wyjątku. Niemniej, jeden z epizodów tej kategorii został przedstawiony w tak interesujący, nieprzeciętny sposób, że zasługuje na bliższe zaprezentowanie, gdyż dzięki niemu choć przez chwilę zobaczyć możemy prawdziwego Teofilakta:

O trzeciej godzinie zaś, znienacka z wodnej głębi wyłoniła się istota o żeńskim kształcie. Naturę jej poświadczała twarz, piersi, delikatność oblicza, włosy, ogólna figura, krągłości, lekkość. Kobieta jaśniała pięknem. Włosy jej były czarne bardziej niż przeciętnie; oblicze białe, nosek kształtny, dłoń o wdzięcznych palcach, pięknie ukształtowane usta. Twarde piersi i wygląd brodawki wskazywały na świeżość młodości. Natura wody strzegła widoku jej łona, chroniąc tajemnicę łoża przed widzami, niczym niewypowiadalną tajemnicę misteriów przed niewtajemniczonymi $^{20}$.

Samo wzmiankowanie o cudownej kobiecie, żyjącej w nurtach Nilu, u Egipcjanina Teofilakta nie dziwi. Warto wszakże zwrócić uwagę na dwie kwestie: a) niezwykły jak na epokę pozytywny realizm, niemalże naturalizm w opisie ponętnych kształtów istoty, b) porównanie jej piękna do tajemnicy misteriów; historyk używa tu słownictwa należącego do terminologii niechrześcijańskich

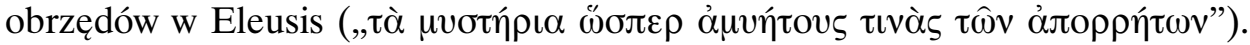
$\mathrm{W}$ ten sposób, nieco filuternie, porównuje skryte pod wodą wdzięki do prawdy, którą poznać mogą tylko wtajemniczeni... Nie można oprzeć się wrażeniu, iż Teofilakt bawi się tu z odbiorcą, pozwala mu dostrzec, iż nie jest niewrażliwy na kobiece piękno. Autentyczności tej jakże osobistej, niemal intymnej jak na ówczesną moralność, scenie, dodaje to, iż nie dołączone zostały żadne odniesienia literackie - to nie konwencja, lecz prawda.

\section{Mit jako alegoria}

Mit jest ulubionym materiałem w bizantyńskich narracjach alegorycznych. Pozbawiony już swego religijnego podłoża, stał się po prostu bogatym źródłem literackich środków wyrazu, symboli, odniesień, przysłów, powszechnie zrozumiałych przez wykształconego Bizantyńczyka. W prozie Teofilakta interesujące jest przede wszystkim to, że używa on języka mitu na określenie pracy literata.

\footnotetext{
${ }^{20}$ Theoph. Sim., 7.16 (trans. AK, ŁR).
} 
Pisanie mianowicie, to podróż, która może zaprowadzić wędrowca w nieznane; każdy pisarz jest zatem Odysem, który musi wiele przejść zanim dopłynie do swojej Itaki, zanim ukończy książkę. Zagrożą mu zawiłości Labiryntu i Syreny, których złudnych pieśni nie wolno mu słuchać ${ }^{21}$. Brzmi to pięknie i wzruszająco nawet dziś. W znakomitej powieści Hanyi Yanagihary z zeszłego roku, Małe życie, czytamy: „Poszedł do kuchni zrobić sobie kawę, a parząc ją, szeptał wersy, które przypominały mu się, ilekroć wracał do domu, na Greene Street, po długim wyjeździe: - «Powiedz, bo nie wierzę, żem już w skałach Itaki». Mieszkanie napełniło się światłem" ${ }^{22}$. Niektóre alegorie żyją już ponad dwa i pół tysiąca lat i nadal poruszają ludzkie serca.

Na tym tle pozostałe alegorie mityczne brzmią już zupełnie trywialnie. Sprowadzają się one zresztą do bardzo pejoratywnych określeń uzurpatora i mordercy cesarza Maurycjusza, Fokasa (602-610), którego Teofilakt nienawidził. Ponieważ jednak w literaturze klasycznej i bizantyńskiej unikano wulgaryzmów, jako zamienników używano imiona postaci, czy szerzej: istot należących do sfery mitu, postrzeganych jednoznacznie negatywnie. Tak też postąpił Teofilakt, który Fokasa porównał do Centaura i dzika z Kalidonu ${ }^{23}$. Podkreślił w ten sposób dzikość i okrucieństwo tego człowieka, jego nieopanowanie, kierowanie się najniższymi popędami. Ówcześni, doskonale te odniesienia rozumieli, ale wówczas nie pisano o emocjach wprost, lecz wyrażano je metaforami, bądź całymi obrazami, które oddziaływały na odbiorcę na zasadzie analogii. „On jest jak Centaur, jest więc zdolny do..." i tu w duszy czytelnika albo słuchacza przypominały się sceny, o których uczył się w szkole albo słuchał w teatrze czy na hipodromie.

\section{Historia jako alegoria}

Niewątpliwie, używanie alegorii historycznej przez Teofilakta pod względem warsztatu pisarskiego reprezentuje najniższy poziom, a czasami jest wręcz chybione. Dlatego nie dziwi, że opisując ogromne straty, jakie Awarowie ponieśli, zdobywając Singidunum (dzis. Belgrad), użył wyrażenia „Kadmejskie zwycięstwo" 24 , chociaż bardziej naturalne byłoby - znane także ówcześnie - synonimiczne „Pyrrusowe zwycięstwo”. Alegoria „Kadmejskiego zwycięstwa” należy do sfery mitu. Aluzja odnosi się do katastrofalnej dla Teb wojny między braćmi, Eteoklesem i Polinejkesem, o miasto, którego Kadmos był założycielem. Dramat rodu Labdakidów to drugi obok dziejów rodu Atrydów i powiązanej z nim wojny trojańskiej, podstawowy krąg wyobrażeń mitycznych greckiej, a później

\footnotetext{
${ }^{21}$ Theoph. Sim., dialog. et praef.

${ }^{22}$ Hanya Yanagihara, Mate życie, trans. Jolanta Kozak (Warszawa: W.A.B., 2015), 508.

${ }^{23}$ Theoph. Sim., dialog., 8.10.

${ }^{24}$ Theoph. Sim., 1.4.
} 
także rzymskiej kultury. Konflikt między dziećmi Ezopa sprawiał, że niezależnie od tego, kto zwycięży, nieszczęścia wojny spadną na mieszkańców Teb. Nawiązując do tej strasznej przeszłości, która, co trzeba zaznaczyć, dla bizantyńskiego historyka była równie realna, co czasy Augusta czy Konstantyna Wielkiego, chciał Teofilakt podkreślić ponadczasowy charakter konsekwencji tego, co działo się na Bałkanach, zarówno dla lokalnej ludności jak i awarskich oraz słowiańskich przybyszy.

Do kategorii alegorii historycznej w naszym rozumieniu przynależą natomiast: nieudane porównanie Filipika do Scypiona ${ }^{25}$, zestawienie znaczenia przemowy Pryskosa ze słynną mową Temistoklesa ${ }^{26}$, opis śmierci anonimowego żołnierza ${ }^{27}$, wreszcie przypowieść o Sezostrisie, najobszerniejsza i najlepiej dopracowana kompozycyjnie ${ }^{28}$.

Porównanie Filipika, dowódcy kampanii rzymskiej w Arzanene wiosną 584 roku, do Scypiona Afrykańskiego (konsul roku 205 p.n.e.), zwycięzcy Hannibala, jest najbardziej niezręczną ze wszystkich alegorii Teofilakta. Historykowi, skoncentrowanemu na pochwale swego ulubionego oficera, umknął istotny fakt, iż Scypion, przenosząc działania wojenne na terytorium wroga, odniósł zwycięstwo ${ }^{29}$. Tymczasem Filipik, uderzając na perską Arzanene, pochorował się jeszcze przed przekroczeniem granicy, a co gorsza, Persowie wyprowadzili kontratak uderzając na rzymskie Tiberiupolis. $\mathrm{W}$ ten sposób pochwała zamieniła się $\mathrm{w}$ farsę. Troszkę tylko lepiej wybrzmiewa druga $\mathrm{z}$ alegorii historycznych. Tym razem jesteśmy na Bałkanach, dowódca rzymski Pryskos przemawia do buntujących się żołnierzy, apelując do ich poczucia patriotyzmu. Odniósł sukces, co Teofilakt odnosi do przemowy Temistoklesa, zrównując w ten sposób znaczenie walk ze Słowianami i Awarami nad Dunajem do wojny obronnej państw greckich z Persją Achemenidów w latach 90 -tych i 80 -tych $\mathrm{V}$ wieku p.n.e. Można by przyjąć to rozumowanie, uprawnione w bardzo trudnych czasach przełomu VI-VII wieku, gdy Cesarstwo walczyło o przetrwanie, gdyby nie drobny szczegół. Otóż przyczyną buntu oddziałów naddunajskich były banalne zasady podziału łupu, a cały wysiłek krasomówczy Pryskosa sprowadza się do przekonania ich, by zgodzili się oddać ich większość cesarzowi. Ponownie, z całą siłą uderza czytelnika nieadekwatność alegorii: Pryskos nie może być Temistoklesem tak, jak Filipik nie jest Scypionem!

${ }^{25}$ Theoph. Sim., 1.14 .

${ }^{26}$ Theoph. Sim., 6.7-8.

${ }^{27}$ Theoph. Sim., 2.6.

${ }^{28}$ Theoph. Sim., 6.11.

${ }^{29}$ Vide Howard Hayes Scullard, Scipio Africanus and the Second Punic War (Cambridge: Cambridge University Press, 1930); John F. Lazenby, Hannibal's War (Warminster: Aris \& Phillips, 1978); Eve MacDonald, Hannibal: A Hellenistic Life (New Haven: Yale University Press, 2015). 
Natomiast przykładem egzaltacji dla dzisiejszego czytelnika raczej nieatrakcyjnej jest próba podkreślenia męstwa żołnierza, poległego w bitwie z Persami pod Solachon (586 r.). Walczył on tak zaciekle, że trzeba było aż czterech ran, by go zabić: podbrzusze przebił oszczep, w ramieniu utkwiła włócznia, a dwie strzały przebiły czaszkę w taki sposób, że skrzyżowały się w jego gardle, tak że nie mógł zamknąć ust! Symbolika jest jednoznaczna, lecz o wiele ciekawszy jest dalszy komentarz, w którym Teofilakt porównuje zabitego do Aleksandra, Leonidasa, Kallimacha i Kynegejrosa. Wszyscy wymienieni to dawni bohaterowie wojen z Persją, znani powszechnie ze szkoły elementarnej. Teofilakt w tak mało subtelny sposób pragnie uwypuklić odwieczność konfliktu z sąsiadem ze wschodu. Mijają stulecia, zmieniają się rządy a nawet ustroje i religie, ale rywalizacja między dwiema cywilizacjami trwa, przybierając jedynie odmienne formy. Jak bardzo w tym obrazie ważniejsza od faktu była moc symbolu historiozoficznej refleksji, świadczy to, że historyk nie pomyślał o rzeczy najbardziej przecież wydawałoby się dla nas oczywistej: by zachować dla potomności imię poległego rzymskiego bohatera.

$\mathrm{Z}$ powyższej perspektywy ostatnia alegoria historyczna wygląda znacznie lepiej. Nie ma w niej nic odkrywczego, ale jest adekwatna w przedstawianym kontekście i nie budzi dysonansu. Sezostris to zhellenizowane imię wybitnego faraona XII Dynastii, Senusereta III (1870 r. p.n.e. -1831 r. p.n.e. $)^{30}$.W greckiej wizji egipskich dziejów, skupiał on w sobie także wielkie czyny i osiągnięcia władców XIX Dynastii, do czego mógł się przyczynić okazały kompleks grobowy z piramidą w Dahszur ${ }^{31}$. Był idealnym wyobrażeniem potęgi oraz specyfiki Egiptu, stąd wiązano z jego imieniem rozmaite anegdoty i przypowieści, które stały się powszechnie znane ludziom wykształconym, aczkolwiek nie miały one absolutnie nic wspólnego z prawdziwym faraonem. Stanowiły po prostu element wspólnego kodu kulturowego. Należy do nich chociażby szczegółowa relacja Herodota $^{32}$. Dwukrotnie nawiązuje do niej np. Józef Flawiusz. Raz, w celach polemicznych, gdy sugeruje, iż w osobie Sezostrisa pomieszano czyny innych faraonów ${ }^{33}$; drugi, gdy krytykując Apiona, nawiązuje do ślepoty syna Sezostrisa, Ferosa $^{34}$. Ten ostatni przypadek jest o tyle interesujący, że pokazuje jak rodzi się przysłowie: ze starej opowieści o charakterze antykwarycznym autor tworzy

${ }^{30}$ Należy pamiętać, iż w chronologii staroegipskiej daty przed 664 r. p.n.e. są uważane za niepewne i podlegają ciągłym modyfikacjom; datacja Senusereta III za: A Companion to Ancient Egypt I-II, edited by Allan B. Lloyd (Oxford: Oxford University Press, 2010: xxxv).

${ }^{31}$ Claude Obsomer, Les campagnes de Sésostris. Essaie d'interprétation du texte grec à la lumière des réalités égyptiennes (Bruxelles: Safran, 1989); Pierre Tallet, Sésostris III et la fin de la XIIe Dynastie (Paris: Pygmalion, 2005).

${ }^{32}$ Herodotus, 2.106-111.

${ }^{33}$ Antiquitates Iudaicae, 8.254.

${ }^{34}$ Contra Apionem, 2.133. 
wyrażenie przysłowiowe, by wzmocnić własną vis persuadendi: „zostać oślepionym przez Sezostrisa” brzmi przecież lepiej aniżeli „stracić głowę, oszaleć”. Dlatego też, sam fakt znajomości przez Teofilakta tej przypowieści nie powinien ani zaskakiwać, ani być powodem specjalnego uznania. Przytaczają ją bowiem tacy autorzy, jak Diodor ${ }^{35}$ (jakkolwiek nie mamy jej w zachowanych fragmentach Manetona ${ }^{36}$ ), których każdy Bizantyńczyk kończący szkoły dobrze znał. Nie o erudycję tu zatem chodzi, ale o sposób i kontekst wykorzystania przez autora Historii powszechnej, o to, co zamierzał on poprzez wykorzystanie tej opowieści osiągnąć. Mamy rok 593, Cesarstwu grozi ponowny najazd Awarów na Trację. Rzymianie wysyłają zatem do kagana posła Teodora, który stara się powściągnąć pychę awarskiego władcy, opowiadając przypowieść o Sezostrisie. Rzymianin wybrał tą, w której zwycięski faraon kazał zaprząc do swego powozu władców podbitych krain. Podczas jazdy, jeden z nich, opierając się, wygłosił do faraona pouczenie, iż los zmienny jest, niczym bieg kół. Poruszony faraon uwolnił zaprzęg. Opowieść ta jest bardzo grecka, reprezentuje jedno z niezliczonych ostrzeżeń przed hybris - gdy człowiek, przekraczając wyznaczone mu granice, zdąża ku samozagładzie. Kagan zrozumiał ponoć przesłanie, zgodził się nie wznawiać konfliktu w zamian za odszkodowanie rzeczowe. Nie ma najmniejszych wątpliwości, że takiej mowy w rzeczywistości nie było. Niemożliwe, by władca nowoprzybyłych z Azji, tureckich koczowników zrozumiał cokolwiek $\mathrm{z}$ opowieści o mądrym, egipskim faraonie sprzed ponad dwóch tysięcy lat. Oczywiście, pertraktacje miały miejsce, ale o tym, o czym naprawdę rozmawiano, nigdy się nie dowiemy. Dla Teofilakta bowiem, od faktograficznej wierności ważniejsze było przesłanie aksjologiczne. Wpleciona przezeń opowieść o faraonie z pradawnych czasów Średniego Państwa przeniosła negocjacje z 593 roku na wyższy poziom. Alegoria idealnego władcy, wolnego od hybris, pozwoliła na ocenę postępowania kagana wolną od uwarunkowań hinc et nunc, lecz uniwersalną, zachowującą swą aktualność dla każdego czasu i każdej epoki, w których rozumie się jeszcze kulturę grecką. Chcesz wiedzieć, jak rządzić - bądź jak Sezostris! Erudycja, jak wspomniano wyżej, schodzi w tym przypadku na dalszy plan. Dla Teofilakta istotniejsze jest pisanie językiem wartości i wyobrażeń, podzielanych przez swoich odbiorców. Obraz Sezostrisa przemawiał do nich bardziej, niż subtelne rozważania na temat realiów bałkańskiego pogranicza.

\footnotetext{
${ }^{35}$ Diodor, $1.53-58$.
}

${ }^{36}$ Fragm. 34-37 ed. Waddell. Maneton pisze o 48 lat panowania, podbojach w Azji i Europie oraz o tym, że dla Egipcjan jest „drugim po Ozyrysie”. Ostatnio otrzymaliśmy polskie tłumaczenie zachowanych fragmentów twórczości Manetona: Filip Taterka, Manethon $z$ Sebennytos. Dzieje Egiptu („Rhomaioi” 8, Poznań: Wydawnictwo Naukowe UAM, 2017). Opis XII Dynastii znajduje się na s. 79-82. 


\section{Literatura jako alegoria}

Epizody przynależące do tej kategorię podzielić można na dwie grupy: pierwsza to dalsza refleksja autora nad twórczością pisarską, druga - topos państwa jako okrętu. Pod koniec księgi piątej znajdujemy rozbudowaną formułę, stosowaną przez Teofilakta do zmiany tematu (np. przejścia z relacji bałkańskiej na bliskowschodnią) bądź dygresji:

Jako że w całości przedstawiliśmy w strukturze narracji zagadnienie wojny perskiej, pióro zwróci się teraz ku wydarzeniom w Europie, żeglując czarnym atramentem po stronach ksiąg, aby zakotwiczyć przy brzegu celu, za ładunek mając wielkie czyny, wypełnione wieściami godnymi opowieści ${ }^{37}$.

Jest to ciekawy przykład zastosowania alegorii jako elementu porządkującego narrację. Pozostałe formuły przejścia, jakkolwiek zawierają odautorskie uwagi i przemyślenia, to nie mają już charakteru alegorycznego. Przypadek powyższy należy zatem traktować jako kontynuację refleksji nad pisaniem, którą Simokatta przedstawił na początku dzieła językiem mitu. Kwestia ta musiała go bardzo nurtować, gdyż powraca do niej jeszcze raz w dość zagadkowym kontekście ${ }^{38}$. Mianowicie, opisując $w$ drastycznych słowach mord na rodzinie cesarskiej (602 r.), wtrąca aluzję, że znacznie później, gdy już obalono tyrana Fokasa, recytował publicznie relację o tych wydarzeniach. Porównuje się przy tym do Herodota, który swoje Dzieje czytał mieszkańcom Aten, co niewątpliwie świadczy o jego wysokim poczuciu własnej wartości. Niestety, w tym miejscu tekst się urywa. W jedynym zachowanym kodeksie następują dwie puste strony, co może dać nam jedynie wyobrażenie o rozległości tego epizodu. Nie wiemy kiedy i w jakich dokładnie okolicznościach recytacja miała miejsce: czy Teofilakt przemawiał jako osoba prywatna, czy jako przedstawiciel nowego cesarza Herakliusza. Czy treść była w jakiś sposób powiązana $\mathrm{z}$ tekstem Historii? Jak dokładnie rozumiał Teofilakt nawiązanie do Herodota? Wiemy za mało, by należycie ocenić powyższy obraz, czy był trywialny w swym stworzeniu „nowego Herodota”, „nowej historii wojen perskich", czy też znajdowały się tam jeszcze inne myśli, godne większej uwagi. Tego przy obecnym stanie badań nad twórczością Teofilakta stwierdzić nie możemy.

Druga grupa to dwie alegorie, odnoszące się do toposu okrętu jako państwa. To rzecz znana i bardzo popularna w literaturze klasycznej ${ }^{39}$, rozsławiona w kulturze europejskiej poematem Horacego $O$ navis, referent in mare te novi ${ }^{40}$, ale sięgająca czasów greckiej meliki i pieśni Alkajosa, przepięknego Hymnu do

\footnotetext{
${ }^{37}$ Theoph. Sim., 5.15 (trans. AK, ŁR).

${ }^{38}$ Theoph. Sim., 8.12.

${ }^{39}$ Wolfgang Gerlach, „Staat und Staatsschift”, Gymnasium, no. 48 (1937): 127-139.

${ }^{40} 1.14$.
} 
Dioskurów ${ }^{41}$. Teofilakt wykorzystuje ją dwukrotnie, po raz pierwszy, gdy chwali rządy cesarza Tyberiusza II (578-582):

Niczym uczciwy handlarz sterował bowiem okrętem władzy, tak że w oczywisty sposób również wojna prowadziła sprawy ku lepszemu ${ }^{42}$.

Za drugim razem przenosimy się na dwór perski, gdy pozbawiony władzy szachinszach Hormisdas ${ }^{43}$ mówi do perskich satrapów, którzy go obalili:

Albowiem okręt królestwa, prowadzony przez wielu sterników, zatonie po niewielkim sztormie, gdyż jego ster dzieli się między wiele, sprzecznych zresztą, pomysłów i każdy z nich - to w jedną, to w drugą stronę - wedle własnego planu kieruje stateczkiem ${ }^{44}$.

Należy zwrócić uwagę na interesujący paralelizm w wykorzystaniu alegorii okrętu. W obu przypadkach uwypuklono kluczową rolę władzy monarchicznej, która ma pierwszeństwo nad innymi formami ustrojowymi. Natomiast jakość funkcjonowania państwa zależy tylko od etycznych i merytorycznych przymiotów władcy. Pogląd powyższy był wówczas podzielany powszechnie: ani zastosowany obraz, ani przesłanie, jakie za jego pośrednictwem wyrażono, nie było niczym szczególnym. To, co jedynie może zasługiwać na wzmiankę, to podobne jego zastosowanie w rzymskich i perskich realiach.

W świetle powyższych rozważań można zrozumieć, dlaczego nie spotykamy ani jednej alegorii w kontekście słowiańskim. Otóż Teofilakt, który o Słowianach napisał dużo, nie uznał ich za godnych wysublimowanych struktur narracyjnych. Owi „barbarzyńcy” byli dlań tylko chwilowym zaburzeniem, zależnym od Awarów przedmiotem, a nie podmiotem historii, którzy szybko znikną z horyzontu rzymskiego państwa ${ }^{45}$. Dlatego warto wspomnieć tylko o jednym przypadku interesującego użycia figury słów. Mianowicie, przy przedstawianiu pogromu Słowian grupy Ardagasta, Teofilakt napisał, iż „Rzymianie wielką liczbę Sklawenów uczy-

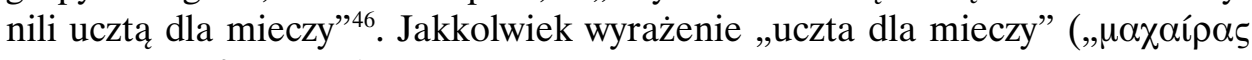

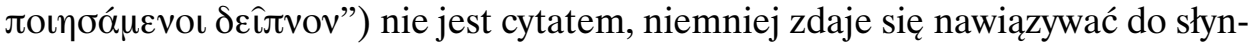
nej frazy z inwokacji Iliady (1.5), gdzie - w wersji Zenodota z Aleksandrii

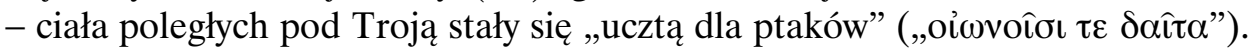

${ }^{41}$ Fragm. 34 ed. Voigt.

${ }^{42}$ Theoph. Sim., 3.16 (trans. AK, ŁR).

${ }^{43}$ Hormozd IV (579-590).

${ }^{44}$ Theoph. Sim., 4.4. Oczywiście, nie należy uważać tych słów za autentyczną wypowiedź Hormisdasa. Mowy (oratio recta) służyły autorom m.in. do wyrażania własnych poglądów. O tej skomplikowanej kwestii zob. Anna Kotłowska, Łukasz Różycki, „The Role and Place of Speeches in the Work of Theophylact Simocatta", Vox Patrum, no. 36 (2016): 353-382 (trans. AK, LR).

${ }^{45}$ Zagadnieniom tym został poświęcony odrębny artykuł, vide Anna Kotłowska, „Słowianie w «Historii powszechnej» Teofilakta Simokatty - bizantyńska perspektywa aksjologiczna” [in press].

${ }^{46}$ Theoph. Sim., 6.7 (przekł. AK, ŁR). 
Powyższe skojarzenie mogło z pewnością pojawić się u odbiorcy tegoż fragmentu, nasuwając plastyczne, a zarazem jednoznacznie brutalne wyobrażenie klęski słowiańskich barbarzyńców.

Podsumowując powyższe rozważania można stwierdzić, iż surowa ocena patriarchy Focjusza była zasadniczo słuszna. Przeanalizowane przypadki zastosowania alegorii, jakkolwiek nieliczne, są albo konwencjonalne, albo tak napuszone i przeładowane topiką, iż nie przynoszą odbiorcy estetycznej przyjemności.

\author{
ALLEGORY IN THE HISTORY BY THEOPHYLACT SIMOCATTA. \\ GROUNDS FOR STUDIES ON THE PRESENCE OF ALLEGORY \\ WITHIN THE NARRATIVE OF BYZANTINE LITERATURE
}

\title{
Su m m a ry
}

The History by Theophylact Simocatta constitutes a very important source for the history of Byzantine civilization in the last two decades of the sixth century, especially within the context of the appearance of the Avars and Slavs in the Balkans. Its importance as a source is also to be valued in the aspect of the Persian conflict on the eastern border.

Photius, the Patriarch of Constantinople (cod. 65, ed. Henry) was very strict in his opinion of the allegories present in Simocatta's prose. The purpose of this paper is to verify the appropriateness of such harsh review by analyzing the presence of allegory in historical narrative in question.

The analysis of all allegorical images present in Theophylact's work has confirmed that the opinion presented by the author of Bibliotheca was indeed proper. Allegories in question prove to be highly conventional, lacking creativity, indistinctive and quite standard for the time. Only the image of Odysseus wandering, which served as allegory of writing, deserves to be called authentic and emotional. Not only are they of middling artistic value, but also they do not provide any help in interpreting the historical events they describe. Moreover, there is one fragment, where the allegory used can be even misleading and cause some misunderstandings of the text.

Nevertheless, other rhetorical structures present in Theophylact's History deserve to be praised, such as the method in which he uses the quotes from the epic. Such quotes are always very smoothly and diligently composed into narrative and designed to strengthen the author's axiological argumentation, which seems to be a universal standard in Byzantine literature. 